\title{
Emergence and Downward Causation Reconsidered in Terms of the Aristotelian-Thomistic View of Causation and Divine Action
}

\section{MARIUSZ TABACZEK OP}

The Notre Dame Institute for Advanced Study - Notre Dame, IN mtabaczek@gmail.com

\begin{abstract}
One of the main challenges of the nonreductionist approach to complex structures and phenomena in philosophy of biology is its defense of the plausibility of the theory of emergence and downward causation. The tension between remaining faithful to the rules of physicalism and physical causal closure, while defending the novelty and distinctiveness of emergents from their basal constituents, makes the argumentation of many proponents of emergentism lacking in coherency and precision. In this article I aim at answering the suggestion of several thinkers to redefine emergence and downward causation in terms of the broader Aristotelian view of causation. In addition, I further develop this interdisciplinary conversation to include theological implications of emergentism, analyzed in reference to Aquinas' understanding of divine action in terms of the same fourfold division of causes-bringing thus natural science, philosophy, and theology into creative and fruitful dialogue.
\end{abstract}

Keywords: emergence; downward causation; hylomorphism; teleology; Aristotle; Aquinas.

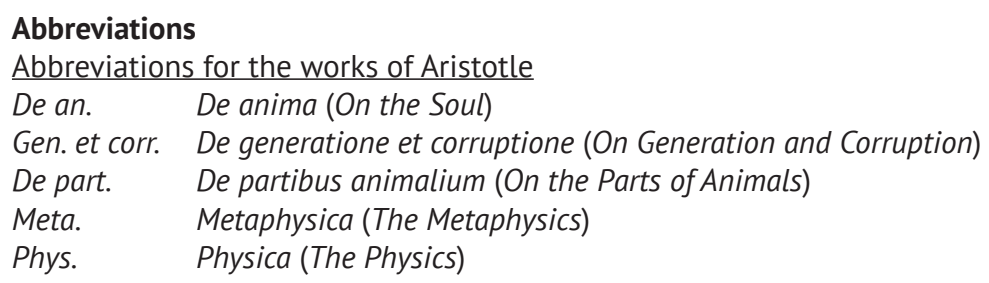


Abbreviations for the works of St. Thomas Aquinas

De prin. nat. De principiis naturae

In De an. In Aristotelis librum De anima commentarium

In Meta. In Metaphysicam Aristotelis commentaria

In Phys. In octo libros Physicorum Aristotelis expositio

In Sent. Scriptum super libros Sententiarum

Q. de an. Questio disputata de anima

Q. de pot. Quaestiones disputatae de potentia

SCG Summa contra gentiles

ST Summa theologiae

[W] do not think that we know anything unless we grasp the "why" which is to grasp the cause. [...] For there resides in every man a natural desire to know the cause of any effect which he sees; and thence arises wonder in man.

Thomas Aquinas, In Phys. II, lect. 5 (§ 176); ST, I, 12, 1, co.

\section{Introduction}

Commenting on the first words of the Book of Genesis-stating that In the beginning, God created the heavens and the earth-Michael Dodds $(2012,1)$ notes that these words tell us two fundamental truths about God: God is, and God acts. But if we believe in a God who acts-he continues-we can talk about God's action only in terms of a broader language of causality. One might think the problem of causation belongs predominantly to natural sciences, which are concerned with changes occurring in nature, and with relations/interactions between entities, systems, and organisms. But the truth is that causal reflection has its roots in philosophy of nature, which also originated the natural sciences as we know them today. Moreover, it turns out that the most robust theory of causation in the history of human thought, which inspired Aquinas' classical view on divine action, was developed in the context of the natural philosophy of Aristotle and his medieval commentators. Although questioned and rejected in modern and early contemporary scientific and philosophical explanation, the Aristotelian fourfold notion of causation has its revival in the context of 
particular philosophical questions raised by natural sciences of today. One of them refers to systems biology and the theory of emergence (EM) and downward causation (DC).

The aim of this article is to show how the Aristotelian-Thomistic theory of causation and divine action can be applied to the philosophical and theological reflection inspired by the biology of complex (irreducible) structures and by dynamic phenomena in nature. The first section begins with some remarks on the nonreductionist approach in contemporary science and philosophy of science. It also offers a short evaluation of the ontological aspects of the theory of EM and DC, which became popular among scientists and philosophers of science reflecting on the phenomenon of biological complexity.

The second section concentrates on an analysis of EM and DC in terms of the Aristotelian fourfold notion of causation. It will show that such redefinition of emergentism requires a rejection of causal monism, which is still predominant in scientific circles. Moreover, it will also prove that any attempt to describe thoroughly the reality of the world has to take into account not only the explanation offered by natural sciences (referring to quantitative aspects of reality), but also the description offered in philosophy of nature and metaphysics (preoccupied with qualitative aspects of nature).

The third section treats about Aquinas' theology of divine action, with reference to his understanding of the nature of divine action and his analysis of God's agency in relation to the division of the four causes. Finally, in the last section, the dialog between natural science and philosophy-introduced in section two-will be further developed to embrace theological implications of EM and DC, analyzed in terms of Aquinas' view on divine action.

\section{Anti-reductionist Turn in Philosophy of Science}

Even if still predominant in various scientific circles, causal reductionism of the modern era has been seriously challenged with the advance 
of contemporary science, and the origin of the discipline of philosophy of science. Our meta-reflection on the nature of scientific progress and some important philosophical aspects of the new scientific discoveries, theories, and hypotheses, helped us realize that the monolithic, cleansed, and tidy reductionist picture-that attracted many scholars and thinkers in the past-does not stand and cannot give a proper account of the actual complexity of nature.

This can be seen in particular in the field of biology. The rapid development of biochemistry and molecular biology in the last century had led many scientists to believe that their reductionist approach-reducing biology to chemistry and chemistry to physics, and limiting all types of causation inherited from ancient and medieval science and philosophy to efficient (physical) causation-would prove to be the only viable and truly scientific method of biological research. Contrary to their expectations, our ability to enter the molecular level of organisms and biochemical processes has opened us to the incredible complexity of the structures, processes and patterns of living organisms, and thus challenged the reductionist paradigm. The intrinsic interrelatedness of different components of natural processes, such as metabolic or cell signaling networks, and their influence on the behavior of organisms, have led many bio-scientists not only to distinguish between various levels of organization of matter in biology, but also to propose a more holistic approach and methodology in biological sciences.

This approach inspired, in turn, a recent revival of the theory of EM, which speaks about the novelty of processes, entities, and properties at higher levels of complexity of matter. It not only strives to develop an ontology of these levels of complexity and characterize the laws of nature which are proper for them, but also speaks about nondeducibility, nonpredictability, and irreducibility of emergents. Most importantly, trying to defend the novelty of emergent properties and phenomena in ontological terms, the followers of emergentism introduce the category of DC, i.e. a new type of causal power characteristic of complex systems, influencing in a top-down manner their basal constituents, and irreducible to the causal operations proper for the lower levels of complexity. 
The theory of EM and DC has become over the last few decades probably the most popular conceptual tool in scientific and philosophical attempts at explaining the nature and character of global organization observed in various phenomena such as magnetization, laser light, crystallization, neural networks, living organisms, collective behavior, or ecological systems. However, closer analysis of emergentism shows a number of philosophical problems that it faces. Probably the most challenging among them refers to the concept of DC and the ambiguity among emergentists in their attempt to specify its nature more precisely. Those who want to remain faithful to the methodology of natural science tend to define DC in terms of physical interactions (efficient causes), which questions its irreducibility. Those who emphasize its novelty and distinctiveness from physical causes find it difficult to identify its ultimate character. They also come at risk of violating the rules of physicalism and causal closure, which they want to follow as scientists and/or philosophers of science. ${ }^{1}$

Realizing the difficulty of this dilemma a group of researchers led by Claus Emmeche suggested that in order to make sense of the theory of EM and keep the notion of DC plausible, we need to expand our understanding of causality in nature:

[Downward Causation] does not involve the idea of a strict 'efficient' temporal causality from an independent higher level to a lower one, rather, the entities at various levels may enter part-whole relations (e.g., mental phenomena control their component neural and biophysical sub-elements), in which the control of the part by the whole can be seen as a kind of functional (teleological) causation, which is based on efficient, material as well as formal causation in a multinested system of constraints (Emmeche, et al. 2000, 25).

Similar is the position of Michael Silberstein who claims that:

Systemic causation means admitting types of causation that goes beyond efficient causation to include causation as global constraints, teleological causation akin to Aristotle's final and formal causes, and the like (Silberstein 2006, 218).

See Kim (1999), 31-33; and Tabaczek (2013), 386-94. 
Following the same way of reasoning A. Moreno and J. Umerez argue for the acceptance of a new type of causation in biological systems, which "is 'formal' in a sense that it infuses forms, i.e., it materially restructures matter according to a form" (Moreno and Umerez 2000, 46).

What we find in these suggestions is an intriguing attempt to retrieve the Aristotelian fourfold division into material, formal, efficient, and final causality. Unfortunately none of the authors mentioned here offers an in-depth analysis of the four causes and their application to EM and DC. I would like to offer such an analysis in what follows. I will build it on both the original Aristotelian reflection on causality, and Aquinas' interpretation and development of the Philosopher's thought.

\section{EM and DC Reconsidered}

\subsection{Ontology of Emergents}

If EM is real, it tells us something important about complex dynamic processes such as laser light, crystallization, or the formation of an eddy in a stream, and dynamic systems/wholes such as living organisms. It is commonly thought that it points toward irreducible features, decisive for their nature and operation (DC). But the whole enterprise of emergentism, analyzed from a philosophical point of view, begs the question of the ontological status of emergents. Trying to answer this question Achim Stephan states:

In the literature on emergence various types of things have been characterized as emergent: laws, effects, events, entities, and properties. However, we should easily agree to explicate the so-called emergent entities and events in terms of emergent properties: An entity is said to be emergent iff it has emergent properties. An event is said to be emergent iff it is an instantiation of an emergent property. Emergent effects, as mentioned by Lewes, have to be interpreted as emergent entities (substances) or properties. Thus, what remains are laws and properties. A law may be called emergent iff it contains emergent properties. Laws may do their work either in the context of transition theories explaining 
changes or in the context of property theories explaining the instantiation of properties by complex systems (Stephan 1992, 27). ${ }^{2}$

The suggestion of Stephan to classify emergents as properties-typical for the analytic metaphysics of particulars which defines them in terms of substratum or bundle theories (see Loux 2006, 84-92)-raises some serious ontological doubts. For metaphysically speaking, properties are always "attached" to something. They are properties of concrete entities, and cannot float freely in nature. Therefore, I find Stephan's suggestion, that the nature of emergents be defined in terms of properties, troublesome and questionable. When we hear him saying that "an entity is said to be emergent iff it has emergent properties," we need to ask about the ontological priority and the metaphysical character of the entity or a group of entities in question. To give an example, is water emergent because it has the properties of liquidity, wetness, viscosity, etc.? Or rather, does it have these properties because it is emergent? This would mean that the very nature of the conglomeration of $\mathrm{H}_{2} \mathrm{O}$ molecules is ontologically different, which makes it exhibit new characteristics that none of $\mathrm{H}_{2} \mathrm{O}$ molecules has when taken separately. If the latter is true, then the emergent character of entities is not reducible to emergent properties characteristic of them.

Similar are the challenges concerning the idea of the redefinition of the emergent character of events in terms of emergent properties. First of all, we must realize the fallacy of the tendency to regard events-in a purely Humean spirit-as causal in their nature. Assigning to events the quality of causation does not give them an independent ontological status. Their occurrence needs to engage concrete entities and becomes a function of cause-effect relations between them. Consequently, Stephan's claim that "[a]n event is said to be emergent iff it is an instantiation of an emergent property," raises again a metaphysical query concerning the ontological ground of the property in question. It must be a property of something,

2 Defining emergents in terms of properties and qualities is probably the most popular position among emergentists, which goes back to the British emergentism (e.g. Samuel Alexander 1920 and Charlie D. Broad 1925). 
and its emergent character requires an ontological base. Therefore, strictly speaking, it is not an event that instantiates an emergent property, but rather it is concrete entities that are constitutive for this event, providing an ontological ground for emergents.

Stephan's attempt to describe new emergent laws in terms of emergent properties seems to be even more confusing. In his claim that "[a] law may be called emergent iff it contains emergent properties," he may be at risk of attributing to the laws of nature an ontological character. Such is at least the flavor of his idea of the containment of emergent properties in a law. As we have said, properties must be mediated by concrete beings (substances in Aristotelian language). They do not have an ontological status on their own. To describe the relation between properties and substances one can use the category of containment, but to suggest a containment of emergent properties in laws of nature, implicitly assigns an ontological status to the latter which is philosophically dubious. However, one might try to defend the position of Stephan against this charge. Continuing his reflection, he states: "Laws may do their work either in the context of transition theories explaining changes or in the context of property theories explaining the instantiation of properties by complex systems." On the base of this assertion we may assume Stephan assigns to laws of nature a descriptive rather than a prescriptive character, and locates the ontological basis of emergent properties in complex systems. If this is the case, however, his own rule of reducing all candidates for emergents to properties is endangered, as complex systems seem to have emergent qualities prior to the properties that originate from them.

\subsection{Emergentism and Hylomorphism}

The criticism of Stephan's position makes even more plausible the suggestion of Emmeche et al., Silberstein, and Moreno and Umerez, to rethink the nature and ontology of emergents in terms of formal causation in the Aristotelian sense. But we must be aware that taking this route requires not only leaving behind causal reductionism and monism-which has dominat- 
ed natural sciences since modernity-but also requires regarding philosophy of nature and ontology as valid and indispensable tools, accompanying natural sciences in their attempts of a thorough description of reality. I think this fact is not emphasized enough by the authors mentioned here. We cannot ignore the fact that reintroducing Aristotelian formal causes is impossible without bringing back his whole theory of hylomorphism, which is defined in terms of philosophical categories that go beyond the methodology of natural science. Thus, in order to redefine EM in terms of formal causation, we need to understand, first, the core of the hylomorphic argument as it was defined by Aristotle and clarified by Aquinas.

Criticizing Plato for his emphasis on the transcendent character of form, which results not only in a certain kind of dualism and devaluation of material reality, but also in a difficulty of his philosophy in explaining change and stability (becoming requires participating in various forms), Aristotle proposes a doctrine of matter and form understood as two causes closely related to each other. He thus defines them respectively in The Physics and The Metaphysics:

In one sense, then, (1) that out of which a thing comes to be and which persists, is called 'cause', e.g. the bronze of the statue, the silver of the bowl, and the genera of which the bronze and the silver are species. In another sense (2) the form or the archetype, i.e. the statement of the essence, and its genera, are called 'causes' (e.g. of the octave the relation of 2:1, and generally number), and the parts in the definition (Phys. II, 3 [194b 24-28]).

'Cause' means (1) that from which, as immanent material, a thing comes into being, e.g. the bronze is the cause of the statue and the silver of the saucer, and so are the classes which include these. (2) The form or pattern, i.e. the definition of the essence, and the classes which include this (e.g. the ratio 2:1 and number in general are causes of the octave), and the parts included in the definition (Meta. V, 2 [1013a 24-29]).

What is crucial regarding the material cause is its not being reducible to basic chunks of stuff which build entities. Although we have difficulty grasping it in the oft cited quotations from The Physics and The Metaphys- 
ics -in which matter seems to be defined as some empirically perceptible stuff (bronze or silver)-for Aristotle matter is a principle of potentiality that persists through all changes that a given substance can be exposed to, something that constitutes the very possibility of being a substance at all. This becomes clear in the following passages from The Physics:

The underlying nature is an object of scientific knowledge, by an analogy. For as the bronze is to the statue, the wood to the bed, or the matter and the formless before receiving form to any thing which has form, so is the underlying nature to substance, i.e. the 'this' or existent (Phys. I, 7 [191a 8-12]).

The matter comes to be and ceases to be in one sense, while in another it does not. As that which contains the privation, it ceases to be in its own nature, for what ceases to be - the privation - is contained within it. But as potentiality it does not cease to be in its own nature, but is necessarily outside the sphere of becoming and ceasing to be. [...] For my definition of matter is just this - the primary substratum of each thing, from which it comes to be without qualification, and which persists in the result (Phys. I, 9 [192a 25-33]). ${ }^{3}$

The key point of the first passage is Aristotle's reference to analogy, which tells us that the underlying nature is not quite the same as perceptible matter. Note also that in the second definition Aristotle does not use the term $\pi \rho \omega \dot{\tau} \eta \dot{v} \lambda \eta$ (primary matter), which is usually associated with his

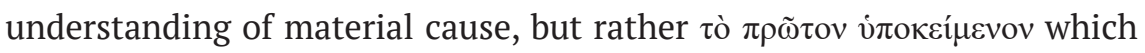
translates as "primary substratum."

Concerning formal cause, Aristotle stands in a radical opposition to the transcendental character of Ideas in Plato. For Aristotle, forms must be in things, determining their actuality. This becomes clear from the quotations from The Physics and The Metaphysics cited above. In both passages Aris-

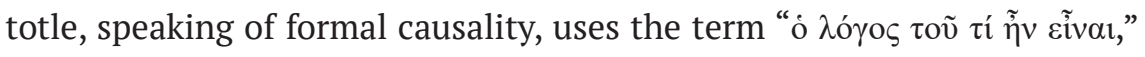
which Gaye translates as "the statement of the essence," and Ross as "the

3 "By matter I mean that which in itself is neither a particular thing nor of a certain quantity nor assigned to any other of the categories by which being is determined" (Meta. VII, 3 [1029a 20-21]). "And if there is a first thing, which is no longer, in reference to something else, called 'thaten', this is prime matter” (Meta. IX, 7 [1049a 24]). 
definition of the essence." 4 However, Aristotle uses also two other terms:

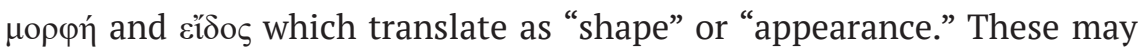
bring confusion and reduction of form to geometrical shape, which flattens out Aristotle's original idea. ${ }^{5}$

Aristotle introduces an important distinction between substantial and accidental form, which is best explained in his example of the two types of changes in nature. In De generatione et corruptione, he first mentions "alteration" (an accidental change), which occurs when a thing or being changes in its properties while remaining the same substance: "The body, e.g., although persisting as the same body, is now healthy and now ill; and the bronze is now spherical and at another time angular, and yet remains the same bronze." He then contrasts it with a situation, "when nothing perceptible persists in its identity as a substratum, and the thing changes as a whole." He calls the latter "a coming-to-be of one substance and a passing-away of the other," e.g. a wooden plank burned into ashes. ${ }^{6}$

When he speaks of material cause, Aquinas emphasizes its character as the principle of potentiality. His explanation is very precise and helps us avoid reducing matter to some basic building blocks. Referring to Aristotle's example of "bronze of the statue," Aquinas states:

$[\ldots]$ although it is the matter with respect to the statue, the bronze itself is composed of matter and form. Therefore bronze is not called prime matter,

4 Phys. II, 3 (194b 26); Meta. V, 2 (1013a 27).

5 See, for instance, Scott (2007), 6. In the second book of The Physics, Aristotle explains briefly that the formal cause answers the question "why" something is the kind of thing it is, but without involving any motion (Phys. II, 7 [198a 17-18]). In Metaphysics I, 3, he refers indirectly to the formal cause defining it as the essence, the ultimate "why," and the ultimate principle: "[C]auses are spoken of in four senses. In one of these we mean the substance, i.e. the essence (for the 'why' is reducible finally to the definition, and the ultimate 'why' is a cause and principle) [...]” (Meta. I, 3 [983a 26-29]). See also Meta. VII, 17 (1041b 11-32).

Aristotle uses one more term: $\dot{\varepsilon} v \tau \varepsilon \lambda \dot{\varepsilon} \chi \varepsilon 1 \alpha$, which relates formal to final causation and denotes form as actualized in the final state of a being. "It is form ( $\mu о \rho \varphi \eta)$, therefore,

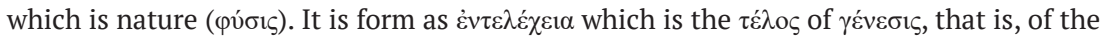
coming-to-be of $\varphi v \sigma^{\prime} \varsigma$. In its state of completion, $\varphi v ́ \sigma ı$ is synonymous with $\dot{\varepsilon} v \tau \varepsilon \lambda \varepsilon \dot{\varepsilon} \chi \varepsilon 1 \alpha$, the

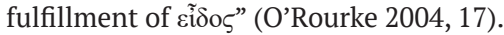

6 See Gen. et cor., I, 4 (319b 10-18). 
even though it has matter. However, that matter which is understood without any form and privation, but rather is subject to form and privation, is called prime matter by reason of the fact that there is no other matter before it ( $D e$ prin. nat. 14). ${ }^{7}$

Aquinas notices that primary matter, as a principle of potentiality, is characterized by a certain kind of privation, which "causes" it to seek form. But he is careful to add that primary matter must not be identified with privation itself, and for two reasons.

First, matter is non-being accidentally, whereas privation is non-being per se. (...) Secondly, matter is 'near to the thing' and exists in some respect, because it is in potency to the thing and is in some respect the substance of the thing, since it enters into the constitution of the substance. But this cannot be said of privation (In Phys. I, lect. 15 [§ 132]). ${ }^{8}$

This assertion helps us acknowledge another feature of primary matter, namely, that it cannot be defined or known by itself, but only as being informed, since all that we know of it, we know through its form. ${ }^{9}$ For this reason, matter together with form can be regarded as "mutual causes of being," matter as a cause of form, inasmuch as it supports it in being, form as a cause of matter, inasmuch as it gives it its actual being. ${ }^{10}$ From this we can infer that form is not added to matter from the outside. Quite the contrary, all forms are present in primary matter as a possibility, and are educed from its potentiality. This assertion in turn inspires Aquinas to sug-

See also Wippel (2000), 312-20.

8 See also In Meta. V, lect. 2 (§ 763). In De prin. nat. Aquinas emphasizes that privation is not an active principle: "It is clear, therefore, according to the opinion of Aristotle that privation, which is posited as a per accidens principle of nature, is not a capacity for a form, nor an inchoate form, nor some imperfect active principle, as some say. Rather it is the very absence of form, or the contrary of form, which occurs in the subject" (De. prin. nat. 113). Wippel (2007, 240-71) offers a good introduction to Aquinas' Commentary on Aristotle's Metaphysics.

9 See De prin. nat. 14 and ST I, 66, 1, ad 3. Commenting on Physics, Aquinas sides with Aristotle who claims that we know primary matter only by analogy.

10 See In Meta. V, lect. 2 (§ 775); Meta. VIII, 6 (1045b 18-21). 
gest that matter must be properly disposed to receive a particular form. ${ }^{11}$

Aquinas characterizes formal cause as that which makes a thing to be what it is. He says that form "causes the quiddity of the thing." ${ }^{12}$ In other words, "the form of a thing is [...] the intelligible expression of its quiddity, i.e., the formula by which its quiddity is known." That is why "it is from a thing's form that the principal part of the definition comes." ${ }^{13}$ On another occasion, Aquinas repeats one more time that it is form "by which a "particular thing' actually exists." ${ }^{14} \mathrm{He}$ also distinguishes between substantial form, which gives being to matter in an absolute way, and accidental form, which does so merely "in a qualified sense." ${ }^{15}$ But it appears to me that the most important contribution to Aristotle's teaching on formal causality made by Aquinas is his list of four types of formal causation as defined in his Commentary on Metaphysics:

1. In Aristotle's examples of the goblet made of silver or statue made of bronze, the form is used in a general and somehow unqualified sense. ${ }^{16}$

2. But sometimes many things are brought together to constitute one thing. This can happen in three ways, which are associated with three respective kinds of formal causation:

11 See Q. de pot. 3, 4, ad 7; 5, 1, co.; Q. de an. 9, co. In SCG Aquinas further develops this idea saying about an inclination of matter to be gradually informed by more perfect forms: "Thus, prime matter is in potency, first of all, to the form of an element. When it is existing under the form of an element it is in potency to the form of a mixed body; that is why the elements are matter for the mixed body. Considered under the form of a mixed body, it is in potency to a vegetative soul, for this sort of soul is the act of a body. In turn, the vegetative soul is in potency to a sensitive soul, and a sensitive one to an intellectual one. (...) So, elements exist for the sake of mixed bodies; these latter exist for the sake of living bodies, among which plants exist for animals, and animals for men. Therefore, man is the end of the whole order of generation" (SCG III, 22, 7).

12 In Phys. II, lect. 5 (§ 183); See also In III Sent., d. 27, 1, 1.

13 In Meta. V, lect. 2 (§ 764).

${ }_{14}$ In De an. 2, lect. 1 (§ 215). "[T]he form is called a being, not as that which is, but as that by which something is” (ST I, 110, 2, co.).

15 In Meta. V, lect. 2 (§ 774).

16 That is why some thinkers tend to interpret Aristotle's notion of form merely as a geometrical shape. Aquinas says that here form may be called species: "[T]he form corresponding to such a matter can be called the species" (In Meta. V, lect. 3 [§ 779]). It seems that the category of species has a general and unqualified meaning for him at this point. 
c) things can be united merely by their arrangement (secundum ordinem), as men in the army or houses in a city;

d) things can be united by contact and bond (secundum contactum et colligationem), which is evident in the example of a house and its parts;

e) and sometimes an alteration of the component parts (alteration componentium) is added to above (b), which occurs in the case of a compound (mixtione). ${ }^{17}$

This classification helps to distinguish with a great precision the idea of form understood merely as a geometrical shape or aggregation of building blocks (an accidental form) from the concept of form defined as the source of the quiddity of a thing (a substantial form), which brings alteration to parts united in a whole. ${ }^{18}$

The whole analysis presented here has a crucial meaning for the reconsideration of the theory of EM in terms of a broader notion of causation. The acceptance of Aristotle's hylomorphism enables us to solve the ambiguity of defining emergents in terms of properties. It suggests characterizing them in reference to new substantial forms of more complex/higher entities/organisms and new accidental forms of more complex dynamic processes engaging particular entities (e.g. molecules of $\mathrm{H}_{2} \mathrm{O}$ in an eddy). The novelty of properties characteristic to emergent entities or processes finds its ground in the novelty of substantial and accidental forms proper for them. Thus, we can say that emergent properties describe and reveal the emergent character of higher entities or processes, rather than being decisive about their emergent nature. Moreover, the emergent character of higher entities and processes thus understood is of an irreducible type, as it is defined in terms of qualitative changes, which are not simple consequences or summations of quantitative changes (described in natural sciences and amenable to mathematical analysis).

Finally, the reference to hylomorphism points toward another two types of causation which are crucial for Aristotelian-Thomistic philosophy

17 In Meta. V, lect. 3 (§ 779).

18 For more information on Aquinas' teaching on substantial forms, including human soul, see Wippel (2000), 327-51; Miller (1995), 69-79. 
of nature, and prove to be helpful in our redefinition of EM and DC. I will analyze them in what follows.

\subsection{Emergentism and Efficient Causation}

Among properties characteristic of emergent entities/organisms and processes we find those that express their abilities of activity and reactivity, which are usually described in Aristotelian-Thomistic philosophy in terms of efficient causation. Thus, we can say that the new substantial forms of emergent entities/organisms and processes are decisive about the nature of their efficacy. This observation becomes crucial for the understanding of the nature of DC. As such, it should always be considered in reference to the substantial form of an emergent entity, which decides about its behavior (activity and reactivity). Hence, although the new type of activity proper to such an entity, and classified as an example of DC, can be described in terms of efficient causality, it is possible only with two important qualifications. First, efficient cause analyzed philosophically in reference to the Aristotelian fourfold notion of causation does not stand on its own, without a reference to the substantial form and accidental features of an entity that shows it. This fact relates DC necessarily to hylomorphic analysis of emergent entities and processes, even if it is otherwise a subject of scientific analysis and mathematical description. Second, we have to remember that within the Aristotelian-Thomistic theory of causation, efficient causality has broader meaning than the one defined within the domain of the natural sciences. In his basic definition of efficient causation Aristotle goes beyond physical efficacy and extends it to mental activity:

Again (3) the primary source of the change or coming to rest; e.g. the man who gave advice is a cause, the father is cause of the child, and generally what makes of what is made and what causes change of what is changed (Phys. II, 3 [194b 29-31]). ${ }^{19}$

Interestingly, it is precisely causal activity of the mind that became one of the most common examples of DC in contemporary emergentism, which

19 See also Meta. V, 2 (1013a 29-32). 
pays attention to causes that originate changes in the behavior of emergent wholes, but are hardly measurable quantitatively and hardly describable in the mathematical language of natural sciences.

In his Commentary to Metaphysics, Aquinas follows Aristotle and presents an extended understanding of efficient causation. Referring to the typology proposed by Avicenna he speaks about:

a) perfective (perficiens) efficient cause - which gives the final perfection to a thing;

b) dispositive (disponens) efficient cause - which prepares matter to receive form, e.g., one who organizes materials to build a house;

c) auxiliary (adiuvans) efficient cause - which acts for an end which is not its own, e.g., someone who assists a king in a war (a special example here is secondary cause acting for the end of the primary cause, which will be discussed below);

d) advisory (consilians) efficient cause - which specifies the end and form of the activity, the way in which the first agent, acting by intellect, is related to every secondary agent, natural or intellectual, e.g., the naval architect instructing the shipwright. ${ }^{20}$

The fourth category of efficient causation listed by Aquinas is unique. It not only goes beyond physical efficacy-which makes it important for our understanding of DC-but also introduces the distinction between primary (first) and secondary causation. This distinction, together with Aquinas's acknowledgement of the difference between principal and instrumental causes, proves to be crucial for his theology of divine action. I will come back to it later. In the meantime we have to refer to the fourth type of causation on Aristotle's list and its importance for the theory of EM.

\subsection{Emergentism and Teleology}

In order to complete his explanation of the fact that things are what they are, and can change or even cease to exist, Aristotle introduces one more type of causation, which he defines as follows:

20 See In Meta. V, lect. 2 (§ \&66). 
Again (4) in the sense of end or 'that for the sake of which' a thing is done, e.g. health is the cause of walking about. ('Why is he walking about?' we say. 'To be healthy', and, having said that, we think we have assigned the cause.) The same is true also of all the intermediate steps which are brought about through the action of something else as means towards the end, e.g. reduction of flesh, purging, drugs, or surgical instruments are means towards health. All these things are 'for the sake of' the end, though they differ from one another in that some are activities, others instruments (Phys. II, 3 [194b 32 - 195a 2). ${ }^{21}$

Following Aristotle, Aquinas defines the last-final cause-as "that for the sake of which" something is done or comes to be, i.e. a good proper to a being which can be attained. ${ }^{22}$ He also follows Aristotle when he emphasizes that final causality is present not only in conscious human decisions, but also in the natural world, where it should not be reduced to a mysterious, quasi-efficient causation, directing things according to a pre-established harmony, acting at the present from the future. It is a distinct type of causation, a natural tendency of things to actualize their potencies, i.e. to realize what is proper to their nature: "it is possible for the natural agent to intend the end without deliberation; and to intend this is nothing else than to have a natural inclination to something." ${ }^{23}$ Aquinas builds on Aristotle's

${ }^{21}$ See also Meta. V, 2 (1013a 33 - 1013b 2); Wallace (1997), 52-70.

22 " $\mathrm{T}] \mathrm{h}$ hat for the sake of which something else comes to be is the greatest good 'and the end' of other things, i.e., it is naturally disposed to their end" (In Meta. V, lect. 3 [§ 781]). See also Meta. V, 2 (1013b 26-27); In Phys. V, lect. 5 (§ 181, 186); De prin. nat. 18; and In Meta. V, lect. 2 (§ 771) where Aquinas follows Aristotle claiming that things intermediate between the first and the ultimate end are also ends with respect to things preceding them. Elders $(1993,301)$ notes that "Aristotle distinguishes between an end for the sake of which (the so-called finis cuius gratia) and the end which is someone's benefit (finis cui)." See Meta. XII, 7 (1072b 1-3); De an. II, 4 (415b 2-3). Aristotle makes a connection between teleology and goodness in Meta. XII, 10 (1075a 12-22). Aquinas follows his idea in In Meta. I, lect. 4 (§ 70).

${ }^{23}$ De prin. nat. 19. "[w]e should notice that, although every agent, both natural and voluntary, intends an end, still it does not follow that every agent knows the end or deliberates about the end. To know the end is necessary in those whose actions are not determined, but which may act for opposed ends as, for example, voluntary agents. Therefore it is necessary that these know the end by which they determine their actions. But in natural agents the actions are determined, hence it is not necessary to choose those things which are for the end" (ibid.). "It is absurd to suppose that purpose is not present because we do not observe the agent deliberating” (Phys. II, 8 [199b 26-27]). See also SCG III, 2; Elders (1993), 304-305. 
observation that "in the works of nature the good end and the final cause is still more dominant than in works of art." ${ }^{24}$

The notion of teleology becomes important for the characteristics of EM and DC. Terrence Deacon (2012; and 2014 with Koutroufinis)-who describes EM in terms of new features as functions of constraints, characteristic for dynamical processes, rather than in terms of DC ("increased constraints” versus “closure-denying” emergentism)-emphasizes the importance of intrinsic teleology at the higher levels of organization of matter. He sees it as a crucial factor distinguishing living from nonliving dynamical systems, enabling us to attribute to the former a quality of a primitive "self." But even in reference to the classical version of the theory of EM, we can analyze DC in terms of the new types of teleology, i.e. tendencies to realize new potencies characteristic of a given emergent entity/organism or dynamic process.

\subsection{The True Nature of DC}

Such analysis of teleology, together with the reflection on the formal and efficient causation proper for emergents, shows the interrelatedness of various types of causality which fall under the general term of DC in contemporary philosophical reflection on biological complexity. Armed with the Aristotelian-Thomistic philosophy of nature and metaphysics we were able to specify the exact character of this new type of causation, without falling into reductionism. For unlike physically/mechanically interpreted

24 De part. I, 1 (639b 20-23). Aristotle understands works of art as conscious and planned human activities that aim at achieving an end. He gives an example of a builder and a physician. The category of good applied to nature does not have a moral character and is not referred merely to conscious beings. See SCG III, 3. See also Aristotle's emphasis on the presence of final causality in nature in Physics, II, 8 (199b 15-18). This broad understanding of teleology goes unnoticed by some contemporary thinkers. Emmeche et al. (2000, 17) seem to think of final cause only in terms of a natural, that is, unconscious, inclination toward maintaining the stability of 'an integrated processual whole'. That is why instead of the final cause they refer to a 'functional cause.' Alwyn Scott $(2007,6)$, on the other hand, sees final causality mainly as a desire of an intentional organism. He does not pay enough attention to the final causality inherent to all nature. Thus he struggles with the problem of "purposive answers" in biological sciences. 
efficient causation characteristic of higher levels of complexity, which is reducible to lower level interactions, and amenable to mathematical and quantitative description, formal and final types of causation-proper for a given order of complexity and qualitative in nature-are always irreducible. One cannot, for instance, reduce the form and teleology proper for a living organism to the form and teleology of elementary particles building it. I claim that this redefinition of DC in terms of formal, final, and efficient causality distinctive for emergent entities/processes, both saves its irreducibility and explains its meaning, answering the criticism of those who challenged its spooky and undefined character in writings of many proponents of emergentism.

Interestingly, interrelatedness of various types of causation, proper for given entities and/or causal occurences, and falling under the contemporary category of DC, was noticed by both Aristotle and Aquinas. We have seen them already relating primary mater to substantial form. Moreover, while analyzing efficient and final causality, Aquinas notes they are related as well. The efficient cause is the cause of the final as it begins motion towards it, while the final cause is the cause of the efficient as it is the reason for its activity. ${ }^{25}$ Going still further, Aquinas points toward the relation between formal and final causes saying: "the form and the end coincide in the same thing," and "it must belong to the natural philosophy to consider the form not only insofar as it is form but also insofar as it is the end." ${ }^{26}$ In fact, on numerous occasions we can find him saying, following Aristotle, about the relations between three causes: "Notice, also, that three causes can coincide in one thing, namely, the form, the end and the efficient cause." ${ }^{27}$ At the same time, however, siding again with Aristotle, Aquinas attributes the primacy among causes to the final cause saying: "even though the end is the last thing to come into being in some cases, it

25 See In Meta. V, lect. 2 (§ 775); De prin. nat. 28.

26 In Phys. V, lect. 11 (§ 246).

27 De prin. nat. 34; In Phys. II, lect. 11 (§ 242). "The last three [the form, the mover, 'that for the sake of which'] often coincide; for the 'what' and 'that for the sake of which' are one, while the primary source of motion is the same in species as these" (Phys. II, 7 [198a 25-27]). 
is always prior in causality. Hence it is called the 'cause of causes,' because it is the cause of the causality of all causes." ${ }^{28}$

Naturally, both Aristotle and Aquinas have much more to say on the topic of causal relationships in nature..$^{29} \mathrm{I}$ have selected and discussed only those aspects of their philosophy of causation which prove to be helpful in my attempt of a redefinition of EM and DC. I believe that the analysis presented here becomes, at least in part, a successful realization of the suggestion made by Emmeche et al., Silberstein, and Moreno and Umerez that was mentioned above.

But philosophical analysis of EM and DC in terms of the more robust, fourfold notion of causation, does not exhaust the explanatory potential of emergentism. Reconsidered in terms of the Aristotelian-Thomistic philosophy of nature, the theory of EM and DC stimulates an intriguing inquiry into theological implications of emergentism. Since the main point of reference in such an inquiry is Aquinas' understanding of the nature of divine action and his analysis of God's agency in relation to all four types of causation, I will discuss these issues first.

\section{Aquinas on Divine Action and Four Causes}

\subsection{The Nature of Divine Action}

Because divine action must be a consequence of who God is, we need to begin with a short reflection concerning the character of the divine nature.

${ }_{28}$ In Meta. V, lect. 3 (§ 782). See also In Phys. II, lect. 5 (§ 186); De prin. nat. 29. "Plainly, however, that cause is the first which we call the final one. For this is the Reason, and the Reason forms the starting-point, alike in the works of art and in works of nature" (De part. I, 1 [639b 14-16]).

29 Other important topics related to philosophy of causation, and discussed by Aristotle and Aquinas, include: (1) the distinction between per se and per accidens causes; (2) the reciprocal character of causation; (3) the possibility of one and the same thing being a cause of contrarieties; (4) the difficulty in distinguishing and specifying all four causes in concrete causal situations; (5) simple and composite causes; (6) active and potential causes; (7) the principle of causation saying that what goes from potency to act requires a cause; (8) the principle of proportionate causation stating that effects must be proportionate to their causes and principles; (9) necessary and contingent (suppositional) character of causes; and (10) causality and chance (fortune). All of these issues are addressed and debated in the contemporary debate on causality. Their analysis goes beyond the scope of this article. 
Here, most fundamentally, we learn that-unlike created things: animate and inanimate-God is ipsum esse subsistens. For Aquinas, the material and formal causes described by Aristotle explain the essence (essentia) of every material being. In addition to essence (which explains what a thing is) each thing also requires a distinct principle to explain the fact that it is. Aquinas names this principle esse (the "act of being"). What is at stake here for Thomas is the fact that all creatures receive their esse from God and so are said to "participate" in being. God, on the contrary, is subsistent being itself (ipsum esse subsistens): his essence (essentia) is identical with his existence (esse). As Aquinas explains: "Subsisting being must be one. [...] Therefore all beings apart from God are not their own being, but are beings by participation." ${ }^{30}$ Moreover, unlike creatures, God as ipsum esse subsistens does not have any potentiality. He is, therefore, a pure actuality that cannot change. ${ }^{31}$

This philosophical reflection on essence and existence becomes a point of departure for Aquinas' theology of creation and divine action. Aquinas insists that on God's part there is only one act, the act of God's being (ipsum esse subsistens), though from our human perspective we rightly distinguish the act of creation (creatio ex nihilo) and the act by which the world, once created, is kept in existence (creatio continua). Thomas em-

30 ST I, 4, 2, co. "In Him essence does not differ from existence" (ST I, 3, 4, co.). "Since therefore God is subsisting being itself, nothing of the perfection of being can be wanting to Him" (ST I, 44, 1, co.) "God alone is actual being through His own essence, while other beings are actual beings through participation, since in God alone is actual being identical with His essence" (SCG III, 66, no. 7). See also ST I, 4, 3, ad 4; 104, 1, co.; In I Sent. 37, 1, 1, co.; Q. de ver. 5, 8, ad 9; SCG III, 65, no. 3; Super de causis, 24. On the meaning of ipsum esse subsistens see Te Velde (1995), 119-25.

31 Dodds (2012, 129-30) compares Aristotle's and Aquinas' understanding of potency and act to show that "To Aristotle, act (substantial form) is a determining principle. For Thomas, act (esse) is, in itself, an unlimited or boundless principle. In creatures, of course, neither substantial form nor esse exists apart from its corresponding principle of potency. Both Thomas and Aristotle recognize, however, that there is a being that is 'pure act' apart from all potency. The 'pure act' Aristotle attributes to this being, however, is the determinate perfection of pure substantial form. The 'pure act' Aquinas envisions is the boundless perfection of pure esse. For Thomas, as for Aristotle, pure act is the immovable summit of all perfection. In Aristotle, this is the immovable mover. For Aquinas, it is the God of revelation.” See also Meta. XII, 6 (1071b 20); SCG I, 16; Q. de pot. 7, 2, ad 9; ST I, 3, 1, co.; 3, 4, co. 
phasizes the fact that the act of creatio ex nihilo is not a change in created being (a modification of being), but is rather the production of all created being. The act of creatio continua can be described as the sustaining of creatures in being. ${ }^{32}$ Aquinas attributes both aspects of creation to the providence of God, which he sees as including not only the eternal plan of God ("the reason of order," ratio ordinis), but also the execution of that plan, which he calls "governance." ${ }^{33}$ Moreover, because God is fully actual, we must acknowledge that his action is identical with his being: "God's power is His essence. Therefore, His action is His being. But His being is His substance. Therefore, God's action is His substance." ${ }^{34}$ But if this is the case, it becomes clear that God as the ultimate source of esse cannot be treated as a univocal cause, acting along with the causality of creatures.

32 "Creation is not change" (ST I, 45, 2, ad 2). "[T] he proper effect of God creating is what is presupposed to all other effects, and that is absolute being" (ST I, 45, 5, co.). "[C]reation in the creature is only a certain relation to the Creator as to the principle of its being" (ST I, 45, 3, co.). "[B]eing is the most common first effect and more intimate than all other effects: wherefore it is an effect which it belongs to God alone to produce by his own power" (Q. de pot. 3, 7, co.). "[T]he being of every creature depends on God, so that not for a moment could it subsist, but would fall into nothingness were it not kept in being by the operation of the Divine power" (ST I, 104, 1, co.). "God is the cause not indeed only of some particular kind of being, but of the whole universal being” (ST I, 103, 5, co.). On the unity of creatio ex nihilo and creatio continua see Te Velde (2006), 125. On being as the proper effect of God, see Te Velde (1995), 176-83.

33 "Two things pertain to the care of providence-namely, the 'reason of order,' which is called providence and disposition; and the execution of order, which is termed government. Of these, the first is eternal, and the second is temporal" (ST I, 22, 1, ad 2). "[A] thing's ultimate perfection consists in the attainment of its end. Therefore it belongs to the Divine goodness, as it brought things into existence, so to lead them to their end: and this is to govern" (ST I, 103, 1, co.). "[T]hings are ordered to the ultimate end which God intends, that is, divine goodness, not only by the fact that they perform their operations, but also by the fact that they exist, since, to the extent that they exist, they bear the likeness of divine goodness which is the end for things [...] Therefore, it pertains to divine providence that things are preserved in being" (SCG III, 65, no. 2). See also In I Sent. 39, 2, 1, co.; ST I, 22, 3, co.; 45, 5, co.; 104, 1, co.; SCG III, 77, no. 2.

34 SCG II, 9, no. 4. "Furthermore, an action that is not the substance of the agent is in the agent as an accident in its subject; and that is why action is reckoned as one of the nine categories of accident. But nothing can exist in God in the manner of an accident. Therefore, God's action is not other than His substance and His power." (SCG II, 9, no. 5). See also $S T$ I, 30, 2, ad 3. 
Because "nothing agrees with Him either in species or in genus," 35 God cannot be classified with creatures in the same ontological category. On the contrary, although immanently present in his creation, in the very essence of his divine nature, God must be a transcendent agent, the "cause hidden from every man." 36

But the causality of God is not limited for Aquinas to the Creator's enabling creatures to participate in his divine esse. God's action is also manifested in all four modes of causation defined by Aristotle, which is the subject of my consideration in the following subsections.

\subsection{Divine Action and Material Cause}

Beginning with material cause, we must note that because primary matter is pure potentiality, it would be erroneous to assert that God (total actuality) is the ultimate primary matter of each being. ${ }^{37}$ At the same time, however, it remains clear for Aquinas that primary matter comes from God and retains a likeness to him. Aquinas thus must acknowledge that "also primary matter is created by the universal cause of being." 38 Thomas repeatedly emphasizes that God's action finds its expression in creating and providing primary matter as a source and principle of potentiality, and of all changes in nature. To this he also adds that because primary matter

35 ST I, 25, 2 ad 2; see also In IX De div. nom. lect. 2 (§ 232-59). As an agent God is not contained in any genus. Hence, creatures cannot participate in the likeness of God according to the same specific or generic formality, but only analogically. And because action follows being, God must differ from every other being, not only in esse but also in actio.

36 SCG III, 101, no. 1. On the perfection of God and God as creator, see Gilson (1956), 110-29. He also describes divine simplicity in (1963), 121-35. This conclusion of Aquinas touches on some other important issues, including the understanding of divine transcendence and immanence, and God's relation to the world. Their analysis goes beyond the main object of our concern here.

37 "The third error is that of David of Dinant, who most absurdly [stultissime] taught that God was primary matter" (ST I, 3, 8, co.). See also In I Sent. 34, 1, 2, co.

38 ST I, 44, 2, co. "Although matter as regards its potentiality recedes from likeness to God, yet, even in so far as it has being in this wise, it retains a certain likeness to the divine being" (ST I, 14, 11, ad 3). "Since God is the efficient, the exemplar and the final cause of all things, and since primary matter is from Him, it follows that the first principle of all things is one in reality" (ST I, 44, 4, ad 4). 
cannot exist without form, even in God the idea of primary matter is not distinct from the divine idea of the composite. ${ }^{39}$

\subsection{Divine Action and Formal Cause}

Because formal cause reduces primary matter from potentiality to act, we may appropriately refer to God as the ultimate source of formal causation. Hence, states Thomas, "Form is something divine and very good and desirable." The reason we can say it is divine is because "every form is a certain participation in the likeness of the divine being, which is pure act. For each thing, insofar as it is in act, has form." ${ }^{* 0}$ In other words, through their substantial form, creatures possess, in part, the actuality that is infinite in the Creator. Consequently, God can be said to act in the world as a source of all forms (forma formarum) and the source of all actuality.

At this point Aquinas goes beyond Aristotle's philosophy and his theory of intrinsic formal causation, introducing the Platonic idea of external exemplar forms (causes), which he sees not as subsisting entities, but as ideas in the mind of God: "[I]n the divine mind there are exemplar forms of all creatures, which are called ideas, as there are forms of artifacts in the mind of an artisan." ${ }^{41}$ Aquinas is careful to note that the plurality of divine exemplars is identical with the one divine essence inasmuch as that essence is known by God as imitable. For even if there can be no real multiplicity of ideas in the divine essence, there can be a logical multiplicity of them as objects of God's understanding, which accounts for the diversity of creatures. They imitate God's essence in different ways, as each living and nonliving entity has its own being (esse), distinct from that of every other entity. Moreover, this reasoning enables us to distinguish between the two types of divine exemplarism: the exemplarism of divine ideas-which involves a perfect likeness between a finite being and its representative divine idea; and the exemplarism of the divine nature-which involves the

39 See In I Sent. 36, 2, 3, ad 2; Q. de ver. 3, 5; ST I, 7, 2, ad 3; Wippel (2000), 322-26.

40 In Phys. I, lect. 15 (§ 135). "[A]ll created things, so far as they are beings, are like God as the first and universal principle of all being” (ST I, 4, 3, co.). See also SCG III, 19, no. 4.

${ }^{41}$ Quod.8, 2. 
degrees of imitation (greater or lesser), as none of the finite creatures can imitate the fullness of God's essence. ${ }^{42}$

\subsection{Divine Action and Efficient Cause}

With regard to God as the first source of forms, Thomas reminds us that the likeness between the agent, i.e., the efficient cause, and its effect observed in nature, makes it unreasonable to pass over the natural generators of substantial forms and to claim that God obviates the causality of natural agents. Referring once more to divine exemplars we can say they "concreate" form and matter, while natural agents "generate" things by causing forms to be educed from the potentiality of primary matter.

Consequently, Thomas states that natural agents are the cause of the coming-to-be (causa fiendi) of a thing, while they cannot be the ultimate cause of its being (causa essendi). ${ }^{43}$ But the question still remains with regard to the nature of the efficient causation of creatures in the comingto-be of inanimate and animate entities. Does it interfere or concur with God's action? In the previous sections we have seen God as the source of being, primary matter, and intrinsic substantial forms. We have also discussed the causation of divine exemplars, which Thomas defines as extrinsic forms, i.e., divine ideas in the mind of God. The time has come to ask whether God acts through the efficient causation of natural agents as well, and if he does so, how we can explain the apparent problem of the double agency of God and creatures in causing the same effect.

\subsubsection{Primary and Secondary Causation}

Aquinas sees God as the first source of all efficient causation. He states, "all agents act in virtue of God himself: and therefore He is the cause of action

42 In his detailed study of divine exemplarism in Aquinas, Doolan (2008) notes that although the doctrine posits forms apart from matter, it does not contradict the Aristotelian position. In reference to $Q$. de ver. 3,1 , ad 4 , he reminds us that "natural forms cannot exist immaterially of themselves, but they can acquire an immateriality from the one in whom they exist. This is evident with our own intellects in which they exist in an immaterial way, and so such forms can also exist in an immaterial way in the divine intellect" (Doolan 2008, 82).

43 See In I Sent. 7, 1, 1, ad 3; Q. de ver. 5, 8, ad 8; Q. de pot. 5, 1; ST I, 104, 1. 
in every creature." ${ }^{44}$ At the same time, he introduces important metaphysical distinctions which help him specify the nature of divine efficient action in relation to the efficient causality of creatures. Thomas distinguishes first between God as the "primary cause," and creatures as "secondary causes," emphasizing that "God's immediate provision over everything does not exclude the action of secondary causes; which are the executors of His order." ${ }^{45}$ Since God as the Creator has gifted every creature with its proper causality, according to its nature, his influence cannot interfere with this causality, but must rather be its source. Consequently, while we can say that through the combined agencies of God and the natural agent a particular natural effect comes to be, we must remember

that the same effect is not attributed to a natural cause and to divine power in such a way that it is partly done by God, and partly by the natural agent; rather, it is wholly done by both, according to a different way, just as the same effect is wholly attributed to the instrument and also wholly to the principal agent. ${ }^{46}$

This is possible once we acknowledge that, metaphysically speaking, the transcendent God does not belong to the same order of causes as creatures. Even if "all created things, so far as they are beings, are like God as the first and universal principle of all being" ${ }^{47}$ that is immanently present in their operations, the causation of the Creator transcends that of the creatures infinitely. The influence of the first cause is therefore not only more intense, so that we can state with Aquinas that "God is more especially the cause of every action than are the secondary agent causes." ${ }^{\prime 8}$ We must also realize that God's agency belongs, in its essence, to an entirely different

44 ST I, 105, 5, co.

45 ST I, 22, 3, ad 2. See also ST I, 19, 6, ad 3; 19, 8, co.; 23, 5, co.; 105, 5, ad 2; I-II, 10, 4, ad 2; Doolan (2004), 407; Gilson (1956), 176, 182-84; Te Velde (1995), 170-75.

46 SCG III, 70, no. 8. "[J]ust as it is not unfitting for one action to be produced by an agent and its power, so it is not inappropriate for the same effect to be produced by a lower agent and God: by both immediately, though in different ways" (SCG III, 70, no. 5). See also Doolan (2004), 408-409.

47 ST I, 4, 3, co.

48 SCG III, 67, no. 5. See also ST I, 21, 4, co.; 36, 3, ad 4; Q. de ver. 5, 9, ad 10; Q. de pot. 3, 7, co. 
ontological order, which makes it transcend infinitely the causation of creatures.

\subsubsection{Principal and Instrumental Causation}

The passage from Aquinas' Summa contra gentiles quoted above, in which he attributes causal effects observed in nature to the agency of both God and creatures, introduces a further distinction in the realm of secondary causes, which remains crucial for Thomas' theory of efficient causation. While some secondary causes act according to their natural dispositions, others produce effects beyond their capacities. Aquinas classifies the latter as instrumental causes and emphasizes their dependence on principal causes for their operation. To give an example, a flute played by the flautist produces an effect that exceeds its capacity. Hence, it is an instrumental cause of the sound, which depends on the principal agency of the flautist. However, when we consider the same flautist playing her flute in an orchestra, we realize that her action does not exceed her capacities. To the contrary, it is proportionate to her skills. But at the same time, guided by the gesture of the conductor, she contributes to a greater effect of the sound of the symphony. The flautist can be thus classified as the secondary cause of the symphony, and contributes to it only under the influence of the primary cause (a conductor).

Aquinas applies the distinction between principal and instrumental causation in his theology of divine action. Dodds notes this is a fact of great importance. Since all actions of efficient causality involve a bestowal of being, whether substantially or accidentally, distinguishing between principal and instrumental causes, we describe God as the source of absolute being, bringing the world into existence ex nihilo in the act of the initial creation, and keeping it in being afterward. At the same time, we ascribe to creatures an instrumental causality in the instantiation of new particular beings, through substantial or accidental change. ${ }^{49}$

Consequently, we can further specify and nuance Aquinas' statement that natural agents cannot be the ultimate cause of being of a thing (causa

49 See Dodds (2012), 193-94. 
essendi). I want to argue, together with Wippel, that, although Thomas insists that creatures cannot produce the act of being (esse) ex nihilo, it is nevertheless possible to hold that they can be-in a sense-causes of esse. Since being is always given by God in proportion to form educed from primary matter, if the latter happens through the operation of the instrumental causation of secondary causes, we can state that they areanalogously speaking-instrumental causes of esse. Hence, we find Aquinas saying: "[B]eing is the proper product of the primary agent, that is, of God; and all things that give being do so because they act by God's power." ${ }^{50}$ In other words, they do so as instrumental causes acting under the principal causation of God.

To sum up, we can see that the two metaphysical distinctions offered by Aquinas enable him to argue in favor of divine concurrentism, attributing the source of efficient causation fully both to God and natural agents. His reasoning avoids the charge of overdetermination, as it is based on the ontological distinction between the causation of God and that of his creatures.

\subsection{Divine Action and Final Cause}

The last of the four causes, which both Aristotle and Aquinas regard as the "cause of causes," is the final cause. According to Aquinas, similar to other modes of causation, all forms of natural teleology find their ultimate source in God. He notes that "the end of all things is some extrinsic good," which

50 SCG III, 66, no. 4. See also SCG III, 67, no. 1; II, 21; III. 66, nos. 1-3; no. 5; Q. de pot. 3, 7, co.; ad 3; ad 16; 5, 1, co.; ST I, 45, 5, co.; 104, 1, co. Wippel $(2000,213)$ notes that "[F]or Thomas, whenever a new substance is efficiently caused by a natural or created agent, that agent's causation applies both to the act of being itself (esse) of the new substance and to a particular determination of esse as realized in that substance. Causation of the particular determination (this or that kind of form) is owing to the created efficient cause insofar as it operates by its own inherent power as a principal cause. Causation of the act of being itself (esse) is assigned to it as an instrumental cause acting with the power of God and to God himself as the principal cause of the same. From this it follows that one should not maintain that Thomas denies that created causes can efficiently cause the act of existing or the act of being, at least in the process of bringing new substances into being. See also Doolan (2004), 400-408; Gilson (2002), 210-12. 
is "outside [extrinsic to] the universe." ${ }^{11}$ It is desired by all creatures as they are looking for the fulfillment of their nature. In other words, $\dot{\varepsilon} v \varepsilon \varepsilon \lambda \dot{\varepsilon} \chi \varepsilon 1 \alpha$, an ultimate actualization of form in the final state of a being, bears some likeness to God and his goodness. It brings Aquinas to the conclusion that "everything is [...] called good from the divine goodness, as from the first exemplary effective and final principle of all goodness." ${ }^{52}$ Consequently, we must acknowledge that:

All things, by desiring their own perfection, desire God Himself, inasmuch as the perfections of all things are so many similitudes of the divine being. [...] And so of those things which desire God, some know Him as He is Himself, and this is proper to the rational creature; others know some participation of His goodness, and this belongs also to sensible knowledge; others have a natural desire without knowledge, as being directed to their ends by a higher intelligence. ${ }^{53}$

All things desire God as their end, when they desire some good thing, whether this desire be intellectual or sensible, or natural, i.e. without knowledge; because nothing is good and desirable except forasmuch as it participates in the likeness to God. $^{54}$

Most importantly, as Dodds notes, this influence of God as the first final cause is much more profound than "the force that moves the atoms in Newtonian science." It does not involve any force, or the physical pushing-and-pulling characteristic of efficient causality. It is simply a communication of the perfection and goodness of God, who does not act to attain any fulfillment in his divine action:

51 ST I, 103, 2, co.

$52 S T$ I, 6, 4, co. "God moves as the object of desire and apprehension" (ST I, 105, 2, ad 2). See also In I Sent. 34, 1, 2, co.; ST I, 6, 1, co.; ad 2; I-II, 109, 6, co.

53 ST I, 6, 1, ad 2.

54 ST I, 44, 4, ad 3. "Thus then does God work in every worker, according to these three things. First as an end. For since every operation is for the sake of some good, real or apparent; and nothing is good either really or apparently, except in as far as it participates in a likeness to the Supreme Good, which is God; it follows that God Himself is the cause of every operation as its end" (ST I, 105, 5, co.). See also Gilson (1940), 75; Barnes (2014), 349-61. 
Some things ... are both agent and patient at the same time: these are imperfect agents, and to these it belongs to intend, even while acting, the acquisition of something. But it does not belong to the First Agent, Who is agent only, to act for the acquisition of some end; He intends only to communicate His perfection, which is His goodness; while every creature intends to acquire its own perfection, which is the likeness of the divine perfection and goodness. Therefore the divine goodness is the end of all things. ${ }^{55}$

This remark concludes our short study of Aquinas' understanding of divine action in reference to the fourfold division of causes. At the same time, the enquiry pursued so far encourages an analysis of theological implications of EM and DC, redefined in terms of the same theory of causation. Such analysis is the object of the remaining section of this article.

\section{Emergentism and Divine Action}

If it is true that God is the first and ultimate source of being, the Creator of primary matter, the source of all forms (forma formarum), the first and principal efficient cause, working through secondary and instrumental causation of his creatures, the source of all teleology and the end of all things, then the new emergent levels of complexity, observable in nature and redefined in terms of the fourfold notion of causation, must be an expression of divine action. In other words, since the coherence and plausibility of the irreducible character of EM and DA can be proved and defended with reference to the retrieved classical division of four causes, the dialogue between natural sciences and philosophy can be further extended to include the theological perspective of divine action in and through emergent entities/organisms and dynamical processes.

I claim, together with Aquinas, that God communicates his goodness and perfection through all four types of causation, at all levels of complexity. The theory of EM and DC highlights some particular stages of one and the same process that is an expression of the abundance of God's actuality, which he wants to share with and bestow upon his creation.

55 ST I, 44, 4, co. See also ST I, 25, 2, co.; Dodds (2012), 181-82. 
Although God does this through the secondary causation of natural agents, what he communicates is his very being. Our reflection on divine action in reference to all four modes of causation helps us realize that even if substantial forms are educed from the potentiality of primary matter through the efficient causation of secondary causes, their actuality is ultimately rooted in the pure actuality of God. Similarly, the act of being (esse) of concrete nonliving entities and organisms, even if caused instrumentally by creatures, is never produced by them ex nihilo, but is ultimately rooted in the actuality of God, whose esse is identical with his essentia.

Moreover, as we consider divine exemplars of all emergent entities, we arrive at the same conclusion. Even if these ideas in the mind of God are multiplied according to their relations to things, according to their reality they are nothing other than the divine essence, inasmuch as its likeness can be shared in many different ways by different things. Thus, even if among created things some can be called exemplars of others because of their likeness to those other things (according to the same species or to the analogy of some kind of imitation), their exemplarism has its source in divine essence as well. ${ }^{56}$

Regarding the theological interpretation of new kinds of teleology proper for emergents, we have seen natural finality as the communication of the ultimate perfection and goodness of God as well. For whatever perfection is achieved as the fulfillment of a rational or an irrational creature's nature (i.e., in its $\dot{\varepsilon} v \tau \varepsilon \lambda \varepsilon \dot{\chi} \chi \varepsilon 1 \alpha-$ an ultimate actualization of its form), it bears similarity to the ultimate perfection of God's being, which is "desired" by all creatures. Thus, we agree with Aquinas, repeating once again his important conclusion, which states, "Everything is ... called good from the

56 See Doolan (2008), 19, 102-103. Doolan holds that, for Aquinas, divine exemplarism plays an integral role in the theory of participation. In reference to the twofold divine exemplarism, he notes that a finite being participates in divine nature according to its many perfections inasmuch as it has being, life, goodness, and the like. By contrast, a finite being participates in only one divine exemplar, as it has a particular mode of being, i.e., a determinate nature. The latter does not go without qualification, since divine ideassensu stricto-are not themselves participated but "are rather the 'participabilities' of the likeness of the divine nature as it is known by God, that is, they are his knowledge of the ways in which the likeness of his essence can be participated" (ibid., 249). 
divine goodness, as from the first exemplary effective and final principle of all goodness" (ST I, 6, 4, co.).

\section{Conclusion}

The goal of the research presented here was to show how the Aristotelian-Thomistic theory of causation and divine action can be applied to the philosophical and theological reflection inspired by the biology of complex (irreducible) structures and dynamic phenomena in nature. The importance of this project lies in its actual realization of the preliminary and general suggestion of Emmeche et al., Silberstein, and Moreno and Umerez, to redefine EM and DC in terms of the broader Aristotelian view of causation. ${ }^{57}$ In addition, I have further developed the conversation to include theological implications of emergentism, analyzed in referenced to Aquinas' understanding of divine action in terms of the same fourfold division of causes. I leave it up to the reader to decide whether my project is successful.

One of the most oft cited statements of Aquinas, in which he claims that "grace does not destroy nature but perfects it," was formulated in the context of his affirming the power of human reason, which is indispensable in theology, "not, indeed, to prove faith, [...] but to make clear other things that are put forward in this doctrine" (ST I, 1, 8, ad 2). It is the power of human reason that enables us to penetrate and understand the world we live in. And because the reality of entities, phenomena, and processes taking place in this world is quite complex, our intellect is capable of pursuing its reflection on different levels of inquiry, which we usually classify under domains of natural science, philosophy, and theology. Although distinct in their methodology and objective aims, these three areas of human knowledge should not remain detached from or hostile toward one another. I hope that research presented in this article succeeds in bringing all three of them into creative and fruitful dialogue.

57 Aristotelian thought has its recent revival in analytic philosophy as the metaphysics of dispositions and their manifestations, with its corresponding view of causation. It is an intriguing proposition developed in the context of contemporary science and philosophy of science. Its analysis is a subject for a separate study. 


\section{References}

Alexander, Samuel. 1920. Space, Time, and Deity. Gifford Lectures 1916-18. London: Macmillan.

Aquinas, Thomas. 1926. In Metaphysicam Aristotelis Commentaria. Turin and Rome: Marietti. [English translation: Commentary on The Metaphysics of Aristotle. 2 Vols. Translated by John Rowan. Chicago: Regnery Press, 1961.]

Aquinas, Thomas. 1929. Scriptum Super Libros Sententiarum Magistri Petri Lombardi Episcopi Parisiensis. Edited by P. Mandonnet. Paris: P. Lethielleux. Aquinas, Thomas. 1961. Summa Contra Gentiles. Turin and Rome: Marietti. [English translation: On the Truth of the Catholic Faith: Summa Contra Gentiles. 4 Vols. Translated by Anton C. Pegis et al. Garden City, New York: Image Books, 1955-1957.]

Aquinas, Thomas. 1962. Summa theologiae. Rome: Editiones Paulinae. [English translation: Summa Theologica. 3 Vols. Translated by the Fathers of the English Dominican Province. New York: Benzinger Bros., 1946.]

Aquinas, Thomas. 1965. In Octo Libros Physicorum Aristotelis Expositio. Turin and Rome: Marietti. [English translation: Commentary on Aristotle's Physics. Translated by Richard J. Blackwell, Richard J. Spath, and W. Edmund Thirlkel. Notre Dame, Indiana: Dumb Ox Books, 1999.]

Aquinas, Thomas. 1965. Questiones Disputatae de Potentia Dei. Turin and Rome: Marietti. [English translation: On the Power of God. Translated by English Dominican Fathers. Westminster, Maryland: Newman Press, 1952.]

Aquinas, Thomas. 1968. Questio Disputata de Anima. Edited by J. Robb. Toronto: Pontifical Institute of Medieval Studies. [English translation: Questions on the Soul. Translated by James H. Robb. Milwaukee, Wis.: Marquette University Press, 1984.]

Aquinas, Thomas. 1976. De Principiis Naturae. Vol. 43 of Opera Omnia. Rome: Typographia polyglotta. [English translation: The Principles of Nature. In Selected Writings of St. Thomas Aquinas. Translated by Robert P. Goodwin. New York: Bobbs-Merrill, 1965, 7-28.]

Aquinas, Thomas. 1984. In Aristotelis Librum De Anima Commentarium. Vol. 45/1 of Opera Omnia. Rome: Typographia polyglotta. [English translation: Commentary on Aristotle's De Anima in the Version of William of Moerbeke and the Commentary of St. Thomas Aquinas. Translated by Kenelm Foster and Silvester Humphries. London: Routledge and Kegan Paul, 1951.]

Aristotle. 2001. De Anima (On the Soul). In The Basic Works of Aristotle, edited by Richard McKeon, translated by J. A. Smith, 533-603. The Modern Library Classics. New York: Modern Library. 
Aristotle. 2001. De Generatione et Corruptione (On Generation and Corruption). In The Basic Works of Aristotle, edited by Richard McKeon, translated by Harold H. Joachim, 465-531. The Modern Library Classics. New York: Modern Library. Aristotle. 2001. De Partibus Animalium (On the Parts of Animals). In The Basic Works of Aristotle, edited by Richard McKeon, translated by William Ogle, 641-61. The Modern Library Classics. New York: Modern Library.

Aristotle. 2001. Metaphysica (Metaphysics). In The Basic Works of Aristotle, edited by Richard McKeon, translated by W. D. Ross, 681-926. The Modern Library Classics. New York: Modern Library.

Aristotle. 2001. Physica (Physics). In The Basic Works of Aristotle, edited by Richard McKeon, translated by R. K. Gaye, 213-394. The Modern Library Classics. New York: Modern Library.

Barnes, Corey L. 2014. "Natural Final Causality and Providence in Aquinas.” New Blackfriars 95: 349-61.

Broad, Charlie Dunbar. 1925. The Mind and Its Place in Nature. London: Routledge \& Kegan Paul.

Cooper, John W. 2006. Panentheism-The Other God of the Philosophers: From Plato to the Present. Grand Rapids, Michigan: Baker Academic.

Deacon, Terrence W. 2012. Incomplete Nature: How Mind Emerged from Matter. New York: W. W. Norton \& Company.

Deacon, Terrence W., and Spyridon Koutroufinis. 2014. “Complexity, and Dynamical Depth." Information 5: 404-23.

Dodds, Michael J. 2012. Unlocking Divine Action: Contemporary Science and Thomas Aquinas. Washington D.C.: Catholic University of America Press.

Doolan, Gregory T. 2004. "The Causality of the Divine Ideas in Relation to Natural Agents in Thomas Aquinas.” International Philosophical Quarterly 44: 393-409.

Doolan, Gregory T. 2008. Aquinas on the Divine Ideas as Exemplar Causes. Washington D.C.: CUA Press.

Elders, Leo. 1993. The Metaphysics of Being of St. Thomas Aquinas: In a Historical Perspective. New York: Brill.

Emmeche, Claus, Simo Køppe, and Frederic Stjernfelt. 2000. “Levels, Emergence, and Three Versions of Downward Causation." In Downward Causation. Mind, Bodies and Matter, edited by Peter Bøgh Andersen, Claus Emmeche, Niels O. Finnemann, and Peder Voetmann Christiansen, 13-34. Aarhus, Oxford: Aarhus University Press.

Gilson, Etienne. 1940. The Spirit of Mediaeval Philosophy. New York: Charles Scribner's Sons.

Gilson, Etienne. 1956. The Christian Philosophy of St. Thomas Aquinas. New York: Random House. 
Gilson, Etienne. 1963. The Elements of Christian Philosophy. New York: Mentor-Omega Book.

Gilson, Etienne. 2002. Thomism: The Philosophy of Thomas Aquinas. Toronto/Ontario: Pontifical Institute of Medieval Studies.

Kim, Jaegwon. 1999. “Making Sense of Emergence.” Philosophical Studies: An International Journal for Philosophy in the Analytic Tradition 95: 3-36.

Loux, Michael J. 2006. Metaphysics: A Contemporary Introduction. New York and London: Routledge.

Miller, Fred D. Jr. 1995. “Aristotelian Natural Form and Theology - Reconsidered.” Proceedings of the American Catholic Philosophical Association 69: 69-79.

Moreno, Alvaro, and Jon Umerez. 2000. "Downward Causation at the Core of Living Organization.” In Downward Causation. Mind, Bodies and Matter, edited by Peter Bøgh Andersen, Claus Emmeche, Niels O. Finnemann, and Peder Voetmann Christiansen, 99-116. Aarhus, Oxford: Aarhus University Press.

O’Rourke, Fran. 2004. “Aristotle and the Metaphysics of Evolution.” The Review of Metaphysics 58: 3-59.

Scott, Alwyn C. 2007. The Nonlinear Universe: Chaos, Emergence, Life. Berlin-Heidelberg-New York: Springer.

Silberstein, Michael. 2006. “In Defence of Ontological Emergence and Mental Causation." In The Re-Emergence of Emergence: The Emergentist Hypothesis from Science to Religion, edited by Philip Clayton and P. C. W. Davies, 203-26. Oxford; New York: Oxford University Press.

Stephan, Achim. 1992. "Emergence-A Systematic View on Its Historical Facets." In Emergence or Reduction? Essays on the Prospects of Nonreductive Physicalism, edited by Ansgar Beckermann, Hans Flohr, and Jaegwon Kim, 25-48.

Tabaczek, Mariusz. 2013. “The Metaphysics of Downward Causation: Rediscovering the Formal Cause." Zygon 48: 380-404.

Velde, Rudi A. Te. 1995. Participation and Substantiality in Thomas Aquinas. Leiden, New York, Köln: E.J. Brill.

Velde, Rudi A. Te. Aquinas on God: The "Divine Science" of the Summa Theologiae. Aldershot, Hants, U.K.: Ashgate.

Wallace, William A. 1997. “Is Finality Included in Aristotle's Definition of Nature?” In Final Causality in Nature and Human Affairs, edited by Richard F. Hassing, 52-70. Washington, D.C.: Catholic University of America Press.

Wippel, John F. 2000. The Metaphysical Thought of Thomas Aquinas: From Finite Being to Uncreated Being. Washington, D.C.: Catholic University of America Press.

Wippel, John F. “Thomas Aquinas on Creatures as Causes of Esse.” International Philosophical Quarterly 40: 197-213.

Wippel, John F. Metaphysical Themes in Thomas Aquinas II. Washington, D.C.: Catholic University of America Press. 